\title{
APLIKASI PENCARIAN PERATURAN REGULASI P4GN DI BNN JAWA BARAT
}

\author{
Dadan Ramdan', Ade Mubarok ${ }^{2}$ \\ 1 Universitas Adhirajasa Reswara Sanjaya \\ e-mail: dadanramdan6996@gmail.com \\ ${ }^{2}$ Universitas Adhirajasa Reswara Sanjaya \\ e-mail: adem@ars.ac.id
}

\begin{abstract}
Abstrak
Regulasi P4GN dikeluarkan berupa Peraturan Menteri, Kepala Badan atau Kepala Daerah. BNN Jawa Barat mengelola seluruh regulasi P4GN yang telah dikeluarkan oleh berbagai instansi baik itu Kementerian, Lembaga dan Wilayah. Saat ini jenis pengelolaan yang dilakukan masih berupa pengarsipan dokumen regulasi P4GN. Sehingga menyulitkan pencarian regulasi P4GN dan penelusuran beberapa dokumen regulasi P4GN yang telah dibentuk sebelumnya. Penulis bertujuan membangun sistem informasi berbasis repository yang dapat mengelola arsip regulasi P4GN agar mempermudah proses pencarian regulasi. Metode pengembangan sistem yang akan digunakan adalah Metode waterfall, sedangkan untuk perancang sistem yang digunakan UML dan pembangunan yang akan digunakan dengan bahasa pemograman PHP. Maka hasil diperoleh pada permasalahan dapat memudahkan Pencarian Peraturan Regulasi P4GN dari berbagai instansi pemerintah baik kementerian, lembaga pemerintah dan pemerintah daerah, disimpan dalam sistem informasi pengelolaan regulasi P4GN Badan Narkotika Nasional ini dan regulasi tersebut dapat dikelola oleh staff Badan Narkotika Nasional untuk menjadi repository.
\end{abstract}

Kata Kunci : Pencarian Peraturan Regulasi P4GN,Sistem informasi repository.

\begin{abstract}
P4GN Regulations are issued in the form of Ministerial Regulations, Heads of Agencies or Regional Heads. West Java BNN manages all P4GN regulations that have been issued by various agencies such as Ministries, Agencies and Regions. Currently, this type of management is still in the form of archiving P4GN regulatory documents. This made it difficult to search for P4GN regulations and to search for some of the P4GN regulatory documents that had been previously established. The author aims to build a repository-based information system that can manage P4GN regulatory archives to facilitate the regulatory search process. The system development method that will be used is the waterfall method, while for system designers using UML and the development that will be used with the PHP programming language. Therefore, the results obtained from these problems can facilitate the Search for P4GN Legislations from various government agencies, both ministries, government agencies and local governments, stored in the National Narcotics Agency's P4GN management information system and these regulations can be managed by Agency staff. National Narcotics to be used as a storage area.
\end{abstract}

Keywords: P4GN Regulatory Rule Search, Repository Information System.

\section{Pendahuluan}

Seiringnya penggunaan Narkotika di Indonesia semakin bertambah dari tahun ke tahun. Menurut Kepala Badan Narkotika Nasional (BNN) Komjen Pol Heru Winarko, selama tahun 2019 setidaknya ada sekitar 3,6 juta pengguna narkoba di Indonesia, meningkat kurang lebih $3 \%$ dari tahun sebelumnya sebelumnya (Badan Narkotika Nasional, 2019). Kalangan remaja menjadi pengguna terbesar yakni $28 \%$, meningkat $8 \%$ dari tahun sebelumnya.

Kalangan remaja diduga menjadi target utama karena mereka cenderung menggunakan dalam jangka waktu yang panjang. Padahal menurut Pasal 127 
Undang-Undang Narkotika, sanksi penyalahgunaan narkoba bagi pengguna serendah-rendahnya adalah menjalani rehabilitasi medis dan sosial, serta setinggitingginya pidana penjara paling lama 4 tahun.

Seiring penyalahgunaan narkoba yang semakin menyebar dan merusak generasi bangsa, banyak upaya telah dilakukan oleh pemerintah dan masyarakat untuk mengurangi penyalahgunaan narkoba (Hartini, 2018). Pemerintah melalui DPR RI telah berupaya merevisi UU terkait Narkoba yang telah tertuang pada Undang-Undang Nomor 35 Tahun 2009 tentang Narkotika. Selain itu, pemerintah melalui BNN membuat berbagai upaya pencegahan dan pemberantasan narkoba sebagai bukti komitment negara dalam memerangi penyalahgunaan narkoba (Putra, 2017).

Salah satu upaya Badan Narkotika Nasional (BNN) dalam penyalahgunaan narkoba, maka dibentuklah Pencegahan dan Pemberantasan Penyalahgunaan dan Peredaran Gelap Narkotika dan Prekusor Narkotika (P4GN) serta diperkuat dengan lahirnya Inpres No. 6 Tahun 2018 pada 28 Agustus 2018 (Badan Narkotika Nasional, 2019). Sebagai tindah lanjut Inpres No. 6 Tahun 2018 maka disusunlah regulasi P4GN oleh BNN bersama dengan Kementerian dan Lembaga Pemerintahan lain di berbagai daerah.

Regulasi P4GN dikeluarkan berupa Peraturan Menteri, Kepala Badan atau Kepala Daerah. BNN Jawa Barat mengelola seluruh regulasi P4GN yang telah dikeluarkan oleh berbagai instansi baik itu Kementerian, Lembaga dan Wilayah. Saat ini jenis pengelolaan yang dilakukan masih berupa pengarsipan dokumen regulasi P4GN. Sehingga menyulitkan pencarian regulasi P4GN dan penelusuran beberapa amandemen regulasi P4GN yang telah dibentuk sebelumnya.

Selain itu, penelusuran lembaga yang sudah dan belum mengeluarkan regulasi P4GN pun sulit untuk dicari, padahal regulasi P4GN ini perlu dibuat dan diimplementasikan oleh setiap instansi. Dengan penggunaan teknologi informasi dalam setiap bidang sangat membantu dalam kegiatan sehari-harinya sangat membutuhkan (Mubarok, et al., 2018).

Beberapa kendala dalam pengelolaan regulasi P4GN di lingkungan BNN Jawa Barat ini menyebabkan perlu adanya sebuah sistem yang dapat mengelola, mengarsipkan dan mencari regulasi P4GN yang telah dikeluarkan oleh berbagai instansi.

Sistem informasi repository dapat digunakan untuk mengarsipkan dokumen sehingga memudahkan dalam mencari dokumen yang diinginkan berdasarkan kriteria tertentu (Irwansyah, 2015).

Repository dapat berfungsi juga sebagai portal informasi yang transparan dimana dokumen dapat diunduh dan dibaca oleh berbagai pihak yang membutuhkan (Rengkung, Sentinuwo, \& Karouw, 2015).

Sistem informasi repository ini dinilai dapat memudahkan pencarian sehingga dari sisi waktu lebih efisien dan dokumen dapat lebih mudah diunduh dan diakses oleh berbagai pihak sehingga lebih transparan.

Landasan Teori

Konsep Dasar Sistem Informasi

Sistem merupakan kumpulankumpulan dari komponen yang membentuk satu kesatuan (Tyoso, 2016). menurut Indrajit dalam (Hutahaean, 2015), suatu sistem merupakan kumpulan-kumpulan komponen yang keterkaitan antara satu dengan yang lain.

\section{Model Pengembangan Sistem}

Siklus hidup pengembangan sistem atau disebut juga System Development Life Cycle (SDLC) adalah proses pembuatan sistem model dan mengembangan sistem dengan mengunakan metodologi tersebut. Konsep ini umumnya merujuk pada sistem komputer atau informasi. Salah satu model pengembangan sistem yaitu, model waterfall (Fowler, 2015). Model waterfall merupakan penurunan dari satu fase ke fase lainnya, Sebagai model air terjun (waterfall). Diantaranya yaitu sebagai berikut:

1. Analisis data

2. Perancangan perangkat lunak.

3. Implementasi

4. pengujian sistem

5. pemeliharaan

\section{Unified Modelling Language}

Menurut (Fowler, 2015) bahwa Unified Modelling Language merupakan suatu keluarga notasi grafis, menggambarkan pada sistem perangkat lunak, khususnya sistem yang dibangun menggunakan pemograman berorientasi objek (OO).

\section{Penelitian Terkait}

Penelitian yang dilakukan oleh (Fitriani \& Pakpahan, 2018) berjudul "Aplikasi Sistem Informasi Pengelolaan Arsip Pada Unit Pelayanan Pajak Dan 
Retribusi Daerah Palmerah Jakarta", yang membahas Dalam suatu organisasi peran teknologi informasi sangat diperlukan, terutama dalam hal data pemrosesan dalam organisasi di mana salah satunya adalah sistem manajemen arsip untuk mendukung kelancaran operasi suatu organisasi, untuk mempercepat proses kerja sehingga lebih efektif dan efisien serta manajemen dokumen fasilitasi menjadi lebih teratur. Pengelolaan arsip pajak BPHTB di Unit Pelayanan Pajak dan Retribusi Daerah Palmerah Jakarta masih menerapkan manual sistem manajemen administrasi arsip. Manajemen arsip pajak proses BPHTB masih sedang direkam, dengan cara atau dicatat ke dalam buku sebagai media penyimpanan arsip pajak sehingga jika suatu buku hilang atau rusak akan menyulitkan karyawan untuk melakukan pencarian dan pemeriksaan kembali semua arsip BPHTB diperlukan di kapan saja. Untuk mengatasi masalah tersebut, maka petugas administrasi penulis dalam melakukan manajemen PT arsip, dapat memberikan informasi yang dibutuhkan dengan cepat, dapat meningkatkan efisiensi dan efektifitas pekerjaan proses, serta merampingkan kegiatan organisasi.

Penelitian yang dilakukan oleh (Endra, Rizal, \& Ariani, 2016) yang berjudul "e-Arsip Berbasis Image Archives Management Process Model untuk Meningkatkan Efektifitas Pengelolaan Arsip", penelitian ini membahas Arsip merupakan catatan sebagai memori keberadaan lembaga atau institusi. Peranan Arsip sangat penting dalam suatu lembaga karena Arsip merupakan sumber informasi.

Pada penelitian pertama ini bertujuan untuk merancang dan mendesign sebuah Aplikasi berbasis web yang bersifat Open Source dengan melakukan analisis data, merancang website, merancang database, menguji aplikasi yang akan buat dan mengimplementasikan website tersebut.

Pada penelitian sebelumnya oleh peneliti pertama masih banyak kekurangan maka dengan penelitian kedua untuk bertujuan mengembangkan aplikasi Berbasis Image Arsips Management Process yang memiliki sistem notifikasi dan kontrol dengan media sms dan email, yang dapat secara otomatis penyimpanan Arsip. Maka hasil dari penelitian dapat dimanfaatkan oleh masyarakat yang berbasis web service dan mengembangkan sistem informasi perangarsipan.
Sedangkan pada penelitian yang dilakukan oleh (Hakim, 2016) yang berjudul "Omeka: sebuah Aplikasi Pengelola Arsip Digital dalam Berbagai Format", dengan perkembangan sekarang yang terjadi, informasi tidak hanya disimpan dalam format tercetak, tetapi disimpan dalam format digital. Pengelolaan arsip digital merupakan peran yang sangat penting bagi lembaga arsip. Dengan membaca artikel ini penulis berharap membangun pengelolaan arsip digital dan deskripsi langkah-langkah dalam aplikasi digital.

\section{Metode Penelitian}

Metodologi penelitian yang digunakan pada penelitian ini adalah metode pengembangan sistem Waterfall. Berikut penjelasan dari setiap tahapan metode waterfall:

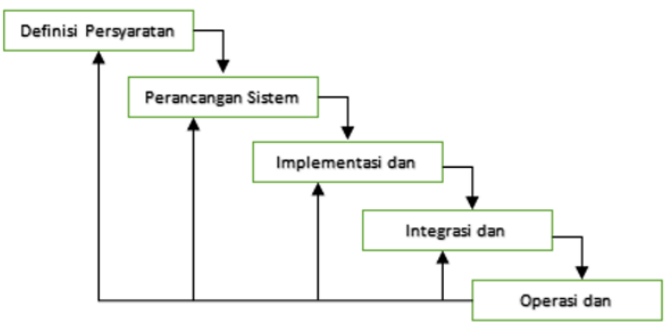

Gambar 1, Metode Waterfall Sumber. (Fowler, 2015).

\section{Analisa Kebutuhan Perangkat Lunak}

Langkah pertama dalam membangun sistem informasi dengan metode model waterfall adalah dilakukan analisis sistem yang berjalan saat ini dan spesifikasi produk yang dibutuhkan berdasarkan permasalahan yang ada. Seperti manajemen pengarsipan regulasi P4GN pada kementerian dan pemerintah daerah di Indonesia belum terkelola dengan baik, sehingga menyulitkan pencarian regulasi pada kementerian dan pemerintah daerah.

Dalam pengumpulan data untuk melengkapi penulisan dalam penelitian ini, dilakukan wawancara dengan staf umum dan tata usaha serta staf khusus P4GN untuk mendapatkan informasi mengenai regulasi-regulasi yang telah dikeluarkan oleh berbagai kementerian dan pemerintah daerah untuk mengetahui kebutuhan data yang diperlukan.

Penulis juga melakukan studi pustaka untuk mencari teori-teori terkait yang relevan terhadap permasalahan yang ditemukan. 
Referensi ini didapatkan dari buku, jurnal, artikel, maupun laporan penelitian yang lain dengan tujuan untuk memperkuat permasalahan yang ditemukan serta sebagai dasar teori dalam melakukan penelitian.

\section{Desain Software dan Sistem}

Dalam tahap desain sistem pengarsipan regulasi P4GN ini, penulis membuat desain pemodelan sistem dan desain basis data. Berikut penjelasannya:

\section{Desain Perangkat Lunak}

Pada pemodelan sistem, penulis menggunakan beberapa contoh dari alat bantu perancangan beroriantasi objek berbasis Unified Modeling Language (UML), diantaranya:

\section{A. Use Case Diagram \\ Use case diagram merupakan} pemodelan kebutuhan (requirements) secara interaksi antara aktor dengan sistem. Dalam sistem pengarsipan regulasi P4GN ini, use case diagram digunakan untuk merancang kebutuhan sistem. Secara umum membahas apa saja yang dapat dilakukan oleh sistem, dan secara khusus menjelaskan pengguna yang akan menggunakan aplikasi ini. Pengguna aplikasi ini akan dibagi menjadi dua yakni administrator selaku pengelola website dan masyarakat umum selaku end-user.

\section{B. Activity Diagram}

Activity diagram menggambarkan aliran kerja atau aktivitas dari sebuah sistem. Pada sistem pengarsipan regulasi P4GN ini, activity diagram digunakan untuk menggambarkan keseluruhan alur dan proses bisnis pada setiap kebutuhan sistem yang sudah dirancang menggunakan use case diagram sebelumnya.

C. Desain Basis Data

Pada desain basis data, Entity Relationship Diagram ERD berfungsi untuk mendokumentasikan dalam sistem pengarsipan regulasi P4GN ini, ERD digunakan untuk menggambarkan entitas apa saja yang diperlukan serta hubungan antar entitas pada database.

\section{Desain Antar Muka}

Pada desain antar muka membahas tentang rancangan antar muka sistem informasi yang akan digunakan sebagai perantara user dengan perangkat lunak. Berikut proses dari desain antar muka:
Tabel 1. Desain Antar Muka

\begin{tabular}{|c|c|c|}
\hline No & Halaman & Keterangan \\
\hline 1. & Login & \begin{tabular}{lr}
\multicolumn{3}{l}{ Untuk mengakses } \\
Sistem Informasi \\
ini, user harus \\
melakukan \\
proses login \\
dengan & cara \\
memasukan & \\
email & dan \\
password. \\
Apabila \\
belum user \\
mempunyai akun \\
untuk melakukan \\
login, user dapat \\
melakukan \\
registrasi terlebih \\
dahulu agar email \\
dan password \\
dapat terdaftar.
\end{tabular} \\
\hline 2. & $\begin{array}{l}\text { Pengelolaan } \\
\text { Regulasi }\end{array}$ & $\begin{array}{ll}\text { Pengelola } & \\
\text { website dapat } \\
\text { mengelola } \\
\text { regulasi-regulasi } \\
\text { yang telah } \\
\text { dikeluarkan oleh } \\
\begin{array}{ll}\text { kementerian dan } \\
\text { pemerintah } \\
\text { daerah. }\end{array} \\
\end{array}$ \\
\hline 3. & $\begin{array}{l}\text { Pengelolaan } \\
\text { Kementerian } \\
\text { dan } \\
\text { Pemerintah } \\
\text { Daerah }\end{array}$ & $\begin{array}{l}\text { Pengelola dapat } \\
\text { mengelola } \\
\text { kementerian dan } \\
\text { pemerintah } \\
\text { daerah yang telah } \\
\text { mengeluarkan } \\
\text { regulasi P4GN } \\
\text { pada halaman. }\end{array}$ \\
\hline 4. & $\begin{array}{l}\text { Halaman } \\
\text { Pencarian } \\
\text { Regulasi } \\
\text { P4GN }\end{array}$ & \begin{tabular}{lr}
\multicolumn{2}{l}{ Masyarakat } \\
umum dapat \\
mencari regulasi \\
P4GN secara \\
mandiri pada \\
laman website.
\end{tabular} \\
\hline
\end{tabular}

\section{Implementasi dan Pengujian Unit}

Dalam tahap Implementasi, desain yang sebelumnya telah dibuat harus ditranslasikan ke dalam program perangkat lunak dengan kode atau bahasa pemograman tertentu yang dimengerti oleh mesin komputer. Maka kegiatan yang dilakukan pada tahap ini sebagai berikut: 
a. Pembuatan Database

Pembuatan database menggunakan mySQL yang diawali dengan pembuatan tabel, dilanjutkan dengan menginput entitas dari setiap tabel tersebut lalu selanjutnya menentukan primary key dan foreign key di dalam tabel tersebut.

b. Pembuatan Sistem Informasi

Pembuatan Sistem Informasi menggunakan bahasa pemrograman PHP dengan framework Laravel.

Selain itu, dilakukan juga pengujian secara fungsional pada setiap unit dari sistem informasi tersebut. Apabila sudah berfungsi dan dapat digunakan sebagaimana mestinya, dilakukan pengujian ke bagian unit yang lainnya. Hasil dari tahap ini adalah program komputer yang sesuai dengan desain yang telah dibuat pada tahap desain.

\section{Pengujian Sistem}

Tahap selanjutnya adalah tahap pengujian sistem. Pada tahap ini, pengujian sistem yang dilakukan yaitu dengan cara pengujian keseluruhan sistem informasi yang telah dibuat. Metode pengujian sistem yang digunakan penulis dalam penelitian ini yaitu metode black box. Pengujian dengan menggunakan metode black box merupakan pengujian yang berfokus pada fungsionalitas dari sebuah sistem. Dalam pengujiannya, pertama membuat test case untuk menguji setiap fungsi yang ada pada sistem tersebut, dan membuat test case untuk menguji apakah alur kerja suatu fungsi pada sistem informasi tersebut sudah sesuai dengan kebutuhan yang diperlukan oleh pengguna.

Dalam pengujian sistem, dapat disimpulkan bahwa untuk menampilkan hasil terbaik dari sistem pengarsipan regulasi P4GN ini, diperlukan minimum requirement alat pendukung pengembangan sistem informasi, seperti:

1. Software Penunjang

a. Sistem Operasi Windows 10 Pro (64-bit)

b. Google Chrome v83.0.4103.106 (32-bit)

2. Hardware Penunjang

a. Processor AMD A10 1.8 GHz

b. Memori DDR3 $8 \mathrm{~GB}$

Sistem pengarsipan regulasi P4GN ini juga dapat diakses dengan baik pada browser Mozilla Firefox v77.0.1 (32-bit) dan tampilan mobile. Untuk browser Internet Explorer v11.0.9600.17842 tampilan antar muka tidak berfungsi dengan baik, seperti beberapa icon dan gambar yang tersedia tidak muncul.

\section{Operasional dan Pemeliharaan}

Tahap akhir dari metode waterfall adalah tahap Operasional dan Pemeliharaan. Tahap ini dapat diartikan sebagai tahap penggunaan perangkat lunak yang disertai dengan perawatan dan perbaikan. Tahap perawatan dan perbaikan suatu perangkat lunak diperlukan, termasuk dengan tahap pengambangan. Maka perangkat lunak tersebut dapat digunakan dan memiliki kekurangan seperti kesalahan yang muncul dan tidak terdeteksi saat pengujian. Pada tahap ini, penulis akan melakukan pengembangan pada sistem perangkat lunak yang sudah dibuat, untuk meningkatkan kualitas pada sistem informasi tersebut.

\section{Hasil dan Pembahasan}

\subsection{Analisa Kebutuhan Perangkat Lunak} Berbagai macam kebutuhan perangkat lunak yang akan dibangun, memerlukan pengembangan perangkat lunak. Oleh karena itu tahap analisa kebutuhan perangkat lunak yang merupakan proses menganalisis dan mengumpulkan kebutuhan-kebutuhan sistem yang sesuai dengan informasi, sistem kerja, dan tampilan antar muka yang diinginkan, guna menentukan solusi perangkat lunak yang akan dibangun. Berikut ini merupakan tahapan analisa kebutuhan perangkat lunak pada sistem usulan ini :

\subsubsection{Tahap Analisis}

Terdapat beberapa pengguna utama dalam sistem informasi regulasi P4GN ini, yakni administrator selaku pengelola website dan pengguna selaku end user dari website regulasi P4GN. Berikut ini merupakan spesifikasi kebutuhan perangkat lunak berdasarkan jenis pengguna:

\section{A. Administrator}

Berikut ini merupakan kebutuhan perangkat lunak bagi administrator yang merupakan pengelola dari sistem informasi ini:

1. Administrator dapat masuk ke dalam sistem informasi

2. Administrator dapat mengelola kementerian

3. Administrator dapat mengelola lembaga pemerintah

4. Administrator dapat mengelola pemerintah daerah

5. Administrator dapat mengelola regulasi

B. Pengguna

Berikut ini merupakan kebutuhan perangkat lunak bagi pengguna yang 
merupakan end user dari sistem informasi ini:

1. Pengguna dapat mencari regulasi P4GN 3.1.2. Analisa Kebutuhan Perangkat Lunak

Use Case Diagram menggambarkan fungsionalitas yang diharapkan dari sistem. Berikut ini merupakan Use Case Diagram dan deskripsi Use Case yang menggambarkan sistem informasi ini:

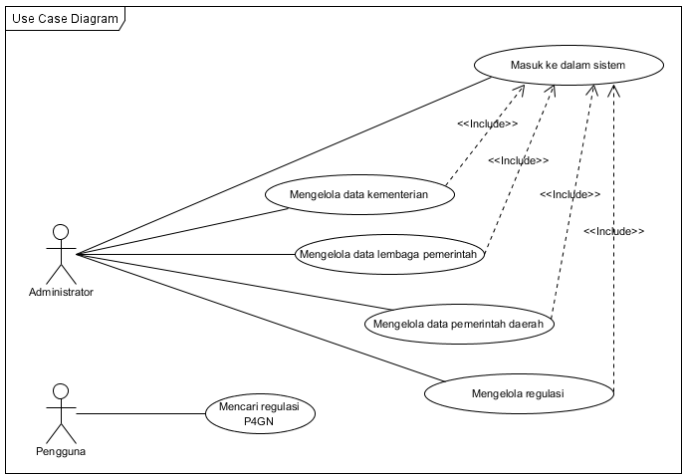

Gambar 2. Use Case diagram

\subsubsection{Activity Diagram}

Activity Diagram adalah teknik untuk menggambarkan logika prosedural, proses bisnis, dan jalur kerja. Berikut ini merupakan Activity Diagram yang menggambarkan Sistem Informasi:

1. Activity Diagram Masuk ke dalam Sistem Informasi

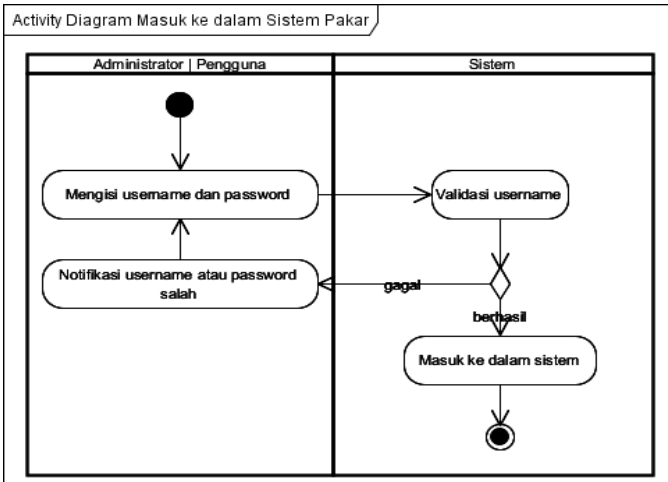

Gambar 3. Activity Diagram Masuk Ke dalam sistem Informasi

\section{Activity Diagram Mengelola Kementerian}

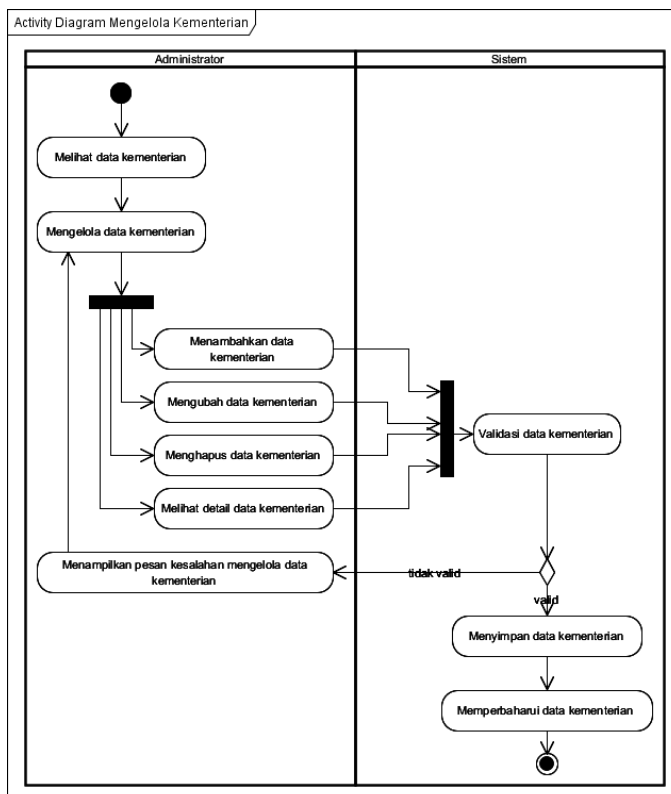

Gambar 4. Activity Diagram Mengelolah Kementrian

3. Activity Diagram Mengelola Lembaga Pemerintah

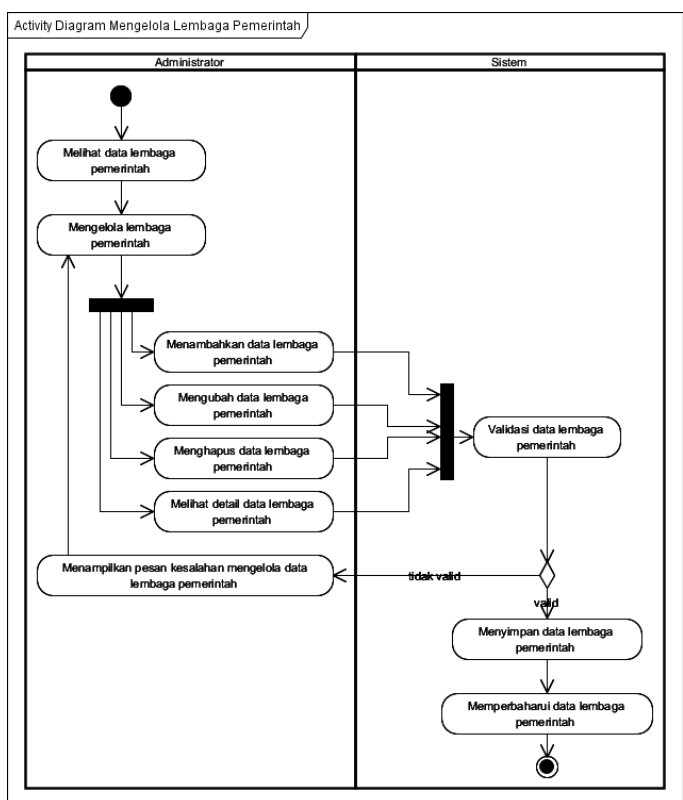

Gambar 5. Activity Diagram Mengelola Lembaga Pemerintahan 
4. Activity Diagram Mengelola Pemerintah Daerah

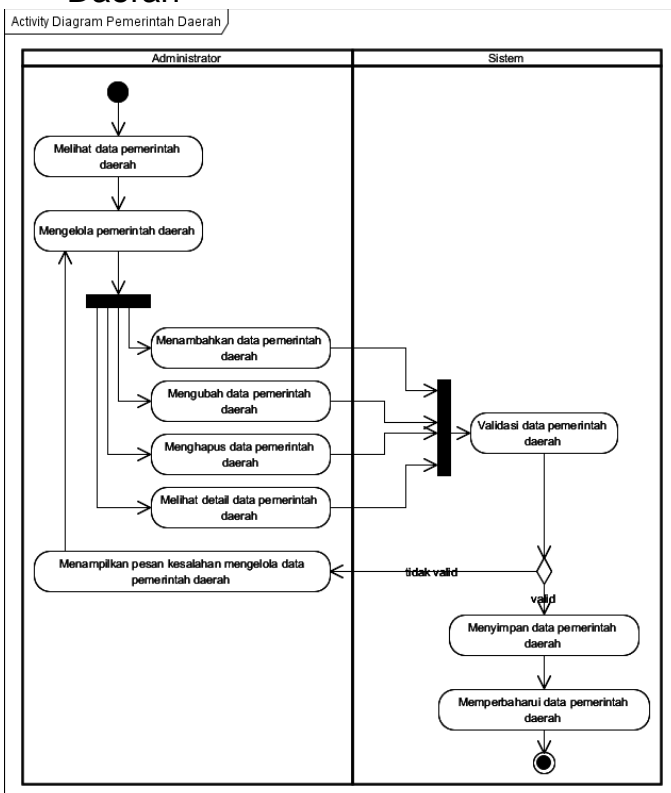

Gambar 6. Activity Diagram Mengelola Pemerintah Daerah

\section{Activity Diagram Mengelola Regulasi}

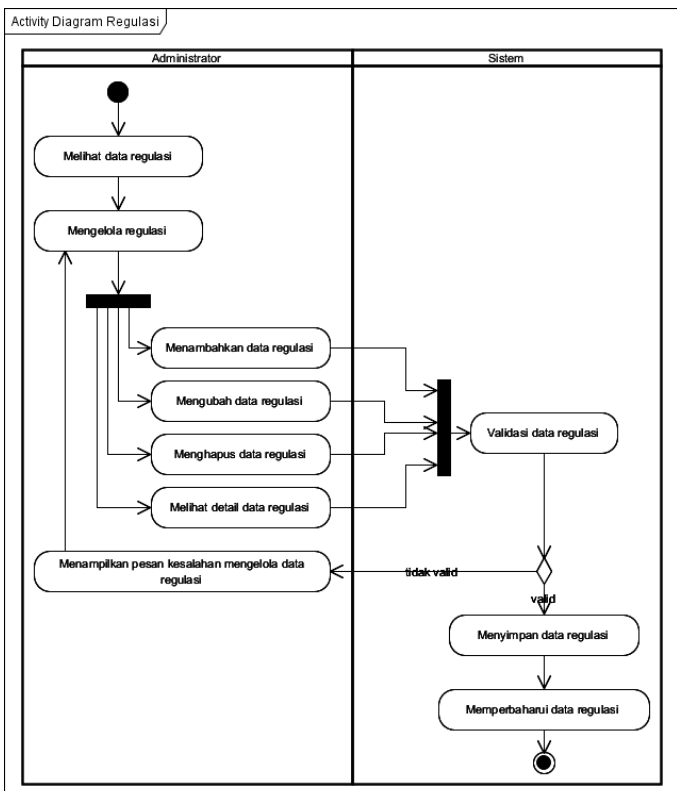

Gambar 7. Activity Diagram Mengelola Regulasi
6. Activity Diagram Mencari regulasi P4GN

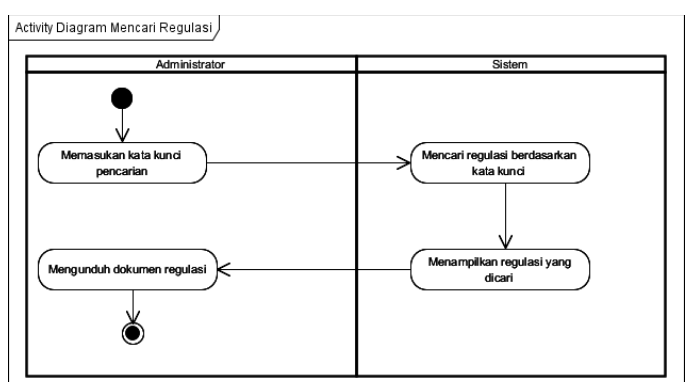

Gambar 8. Activity Diagram Mencari regulasi P4GN

\subsection{Desain}

Tahap desain akan menterjemahkan Kebutuhan - kebutuhan software yang sudah dianalisa pada tahap sebelumnya ke sebuah perancangan perangkat lunak yang dapat diperkirakan sebelum pengkodean

\subsubsection{Desain database}

Desain database menggambarkan tabel-tabel serta relasi antar tabel. Penulis menggambarkan tabel beserta relasinya menggunakan Entity Relationship Diagram atau biasa disebut dengan ERD.

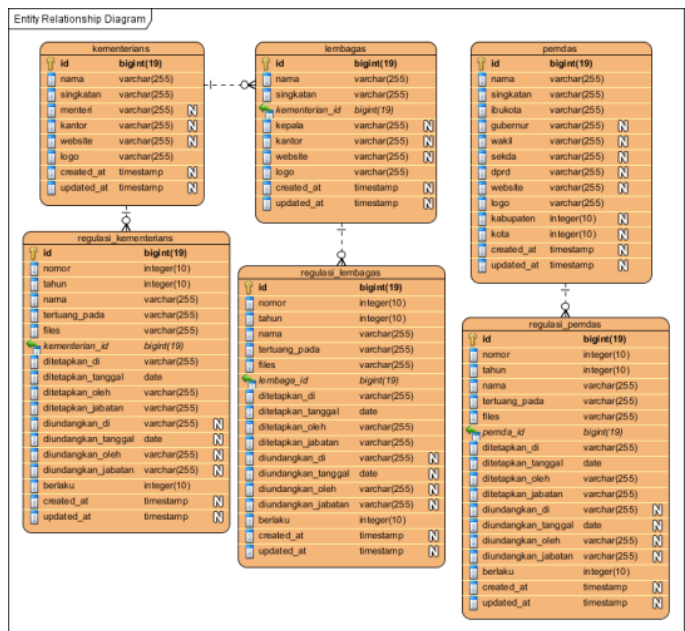

Gambar 9. Desain database

\subsubsection{Software Architecture}

Software

Architecture menggambarkan desain sistem dari sistem yang akan dibuat. Untuk menggambarkan arsitektur perangkat lunak dari sistem yang akan dibuat maka penulis menggunakan component diagram dan deployment diagram. 


\section{A. Component Diagram}

Component

Diagram menggambarkan struktur dan hubungan antar komponen. Berikut ini merupakan Component Diagram dari website yang akan dibuat :

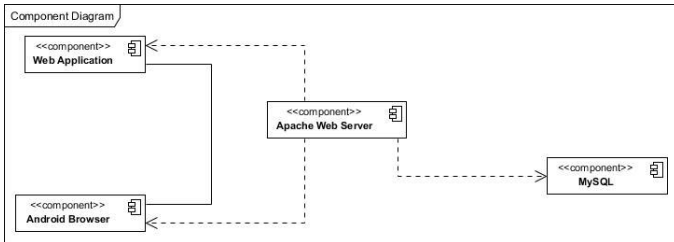

Gambar 10. Component Diagram

\section{B. Deployment Diagram}

Pada Tahap ini Deployment Diagram digunakan untuk menunjukan alokasi artefak pada node dalam desain fisik sebuah sistem. Yang mewakili sebuah gambaran ke dalam struktur artefak suatu sistem. Berikut ini merupakan Deployment Diagram dari website yang akan dibuat :

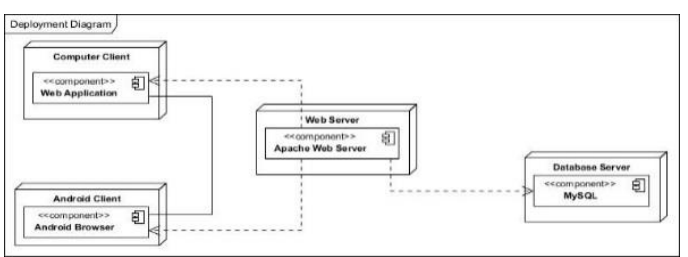

Gambar 11. Deployment Diagram

\subsubsection{User Interface}

Desain User Interface memperlihatkan bagaimanakah bentuk dari perangkat lunak yang akan dibangun nantinya berdasarkan struktur aplikasi yang sudah dibuat. Perancangan antar muka ini meliputi perancangan tampilan input dan perancangan tampilan output.

\section{Halaman Awal}

Halaman awal adalah halaman yang pertama kali muncul pada saat website pertama kali dibuka. Pada halaman ini juga digunakan untuk mencari regulasi P4GN.

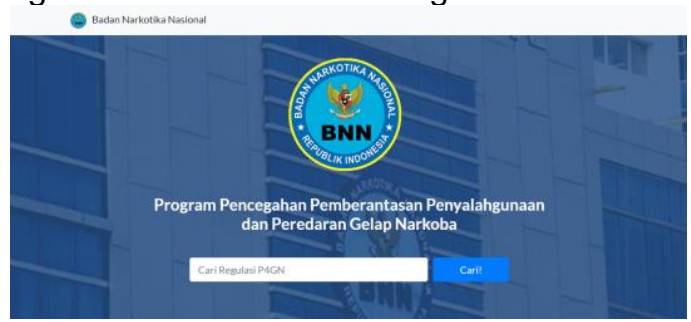

Gambar 12. Halaman Utama

\section{Halaman Login}

Halaman Login digunakan untuk autentikasi pengguna Sistem Informasi, apakah adminstrator atau pengguna. Pada halaman login akan menampilkan email yang berfungsi sebagai username dan kata sandi yang perlu diisikan oleh pengguna kemudian divalidasi oleh sistem. Apabila username dan kata sandi cocok, maka dapat akses ke Sistem Informasi.

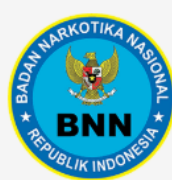

\section{Badan Narkotika Nasional}

Nama Pengguna

Kata Sand

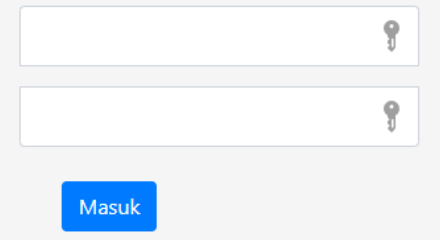

Gambar 13. Halaman Login

\section{Halaman Dashboard}

Halaman dashboard adalah halaman yang pertama kali muncul pada saat administrator berhasil masuk ke dalam sistem. Dalam halaman dashboard dapat dilihat beberapa rekap total regulasi untuk setiap lembaga.

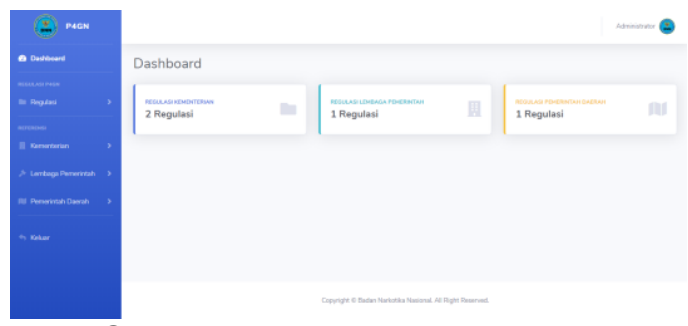

Gambar 14. Halaman Dashboard

\section{Halaman Kelola Kementerian}

Halaman ini digunakan untuk mengelola kementerian. Pada laman ini administrator dapat menambahkan, mengubah dan menghapus data kementerian. 


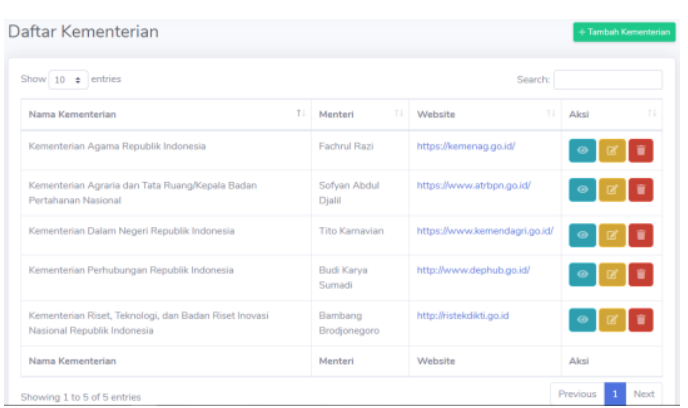

Gambar 15. Halaman Kelola Kementrian

\section{Halaman Kelola Lembaga Pemerintah}

Halaman ini digunakan untuk mengelola lembaga pemerintah. Pada laman ini administrator dapat menambahkan, mengubah dan menghapus lembaga pemerintah.

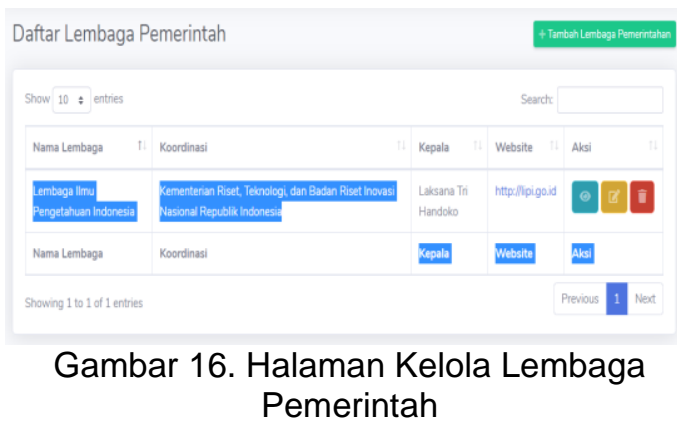

\section{Halaman Kelola Pemerintah Daerah}

Halaman ini digunakan untuk mengelola pemerintah daerah. Pada laman ini administrator dapat menambahkan, mengubah dan menghapus pemerintah daerah.

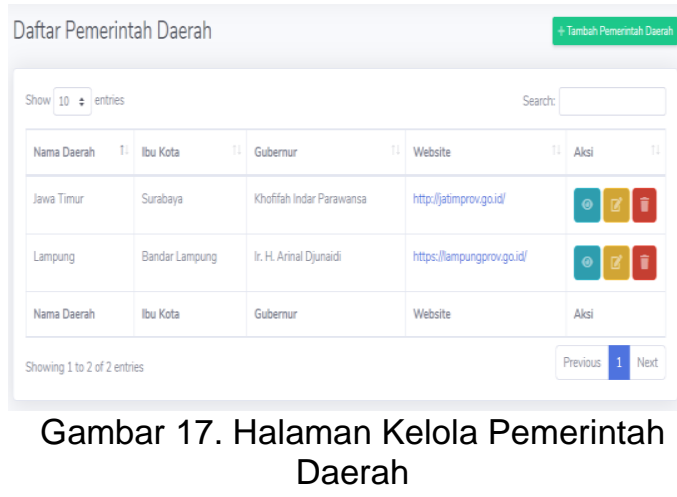

\section{Halaman Kelola Regulasi}

Halaman ini digunakan untuk mengelola regulasi. Pada laman ini administrator dapat menambahkan, mengubah dan menghapus regulasi.

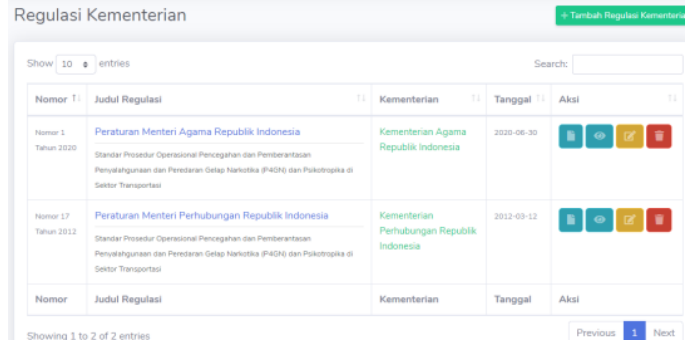

Gambar 18. Halaman Kelola Regulasi

\subsection{Testing}

Pada Proses pengujian atau testing dilakukan untuk memastikan semua pernyataan sudah diuji. Dengan pengujian eksternal fungsional untuk menemukan kesalahan-kesalahan dan memastikan bahwa input akan memberikan hasil yang aktual sesuai kebutuhan. Untuk melakukan pengujian ini, penulis menggunakan metode Black Box untuk menguji website yang sudah dibuat.

\section{Kesimpulan}

Setelah melakukan analisis, perancangan, implementasi dan pengujian, maka diperoleh kesimpulan bahwa:

1. Untuk Memudahkan Pencarian Peraturan Regulasi P4GN dari berbagai instansi pemerintah baik kementerian, lembaga pemerintah dan pemerintah daerah, disimpan dalam sistem informasi pengelolaan regulasi P4GN Badan Narkotika Nasional ini. Regulasi tersebut dapat dikelola oleh staff Badan Narkotika Nasional untuk menjadi repository.

2. Sistem Informasi Pencarian Regulasi P4GN Badan Narkotika Nasional ini dapat diakses seluruh masyarakat publik melalui jaringan internet sehingga dapat memudahkan publik untuk mendapatkan informasi terkait regulasi P4GN.

\section{Referensi}

Badan Narkotika Nasional. (2019, Agustus 12). Penggunaan Narkotika di Kalangan Remaja Meningkat. Diambil kembali dari Badan Narkotika Nasional: https://bnn.go.id/penggunaannarkotika-kalangan-remajameningkat/

Endra, R. Y., Rizal, U., \& Ariani, F. (2016). E-ARSIP BERBASIS IMAGE ARCHIVES MANAGEMENT 
PROCESS MODEL UNTUK MENINGKATKAN EFEKTIFITAS PENGELOLAAN ARSIP. Jurnal Sistem Informasi dan Telematika, 22-32.

Fitriani, Y., \& Pakpahan, R. (2018). Aplikasi Sistem Informasi Pengelolaan Arsip Pada Unit Pelayanan Pajak Dan Retribusi Daerah Palmerah Jakarta . Jurnal Paradigma, 51-56.

Fowler, M. (2015). UML Distilled Second Edition. New York: Addison Wesley.

Hakim, H. B. (2016). OMEKA: APLIKASI PENGELOLA ARSIP DIGITAL DALAM BERBAGAI FORMAT. Jurnal Pengembangan Kearsipan, 23-35.

Hartini, S. (2018). PENDIDIKAN NARKOBA TERHADAP PELAJAR UNTUK MEWUJUDKAN GENERASI BEBBAS NARKOBA. Journal LPPM Universitas Jenderal Soedirman Purwokerto.

Irwansyah, M. (2015). Sistem Informasi Repository Digital Beban Kerja Dosen. Jurnal Edukasi dan Penelitian Teknik Informatika.

Mubarok, A., Riana, D., Sanjaya, R., Prasetyo, R. T., Ramdhani, Y., \& Ali. (2018). Sistem Informasi Pelayanan Online di Mapolresta Bandung. Jurnal Pengabdian Kepada Masyarakat.

Putra, W. S. (2017). UPAYA BADAN NARKOTIKA NASIONAL PROVINSI (BNNP) JAWA TIMUR DALAM MEMBERANTAS

PENYALAHGUNAAN NARKOBA DI KOTA SURABAYA. Jurnal Novum.

Rengkung, R., Sentinuwo, S. R., \& Karouw, S. (2015). Pembangunan Sistem Informasi Repository Berbasis Teknologi Web Component Studi Kasus GMIM Bukit Moria Winangun. Jurnal Teknik Elektro dan Komputer. 